\title{
Studies on Marine Flavobacteria
}

\author{
By P. R. HAYES* \\ Torry Research Station, Aberdeen
}

(Received 14 December 1961)

\begin{abstract}
SUMMARY
Sixty-two pigmented strains, 61 of which had been classified as Flavobacterium species by the workers who isolated them, were studied.

Morphological, cultural, environmental, biochemical and nutritional studies confirmed that 32 non-motile strains were Flavobacterium species; 21 strains were reclassified as presumptive Cytophaga species and the remaining 8 strains were ascribed to the genera Pseudomonas, Vibrio or Corynebacterium, or were unclassifiable. A new genus is suggested for the peritrichous flagellated organisms, previously included in the genus Flavobacterium. Both the flavobacteria and the cytophagas were found to have many properties in common. Satisfactory methods of differentiating between representatives of these genera were limited to the swarming ability and greater heat resistance of the latter. Of the 32 non-motile Flavobacterium strains, 18 were divisible into two well defined groups (? species) and the remainder were a heterogeneous collection. The 22 Cytophaga strains were also divisible into two groups (? species). The possibility of a relationship existing between flavobacteria and cytophagas is discussed briefly.
\end{abstract}

\section{INTRODUCTION}

The genus Flavobacterium is one of the more commonly represented genera in the marine environment; flavobacteria are normally found in the slime and intestines of fresh and spoiling fish. They have also been isolated from sea water, marine muds and seaweed (for reviews see: ZoBell, 1946; Shewan, 1949; Tarr, 1954). The definition of the genus has undergone considerable modification since it was erected in the first edition of Bergey's Manual (1923), where the genus included motile peritrichous- or polar-flagellate, and non-motile Gram-positive and Gramnegative rods. The polar-flagellate forms were removed in the fifth edition of Bergey's Manual (1939). The exclusion of the Gram-positive species was suggested by Gary (1950) and Weeks (1955). The genus, as now defined by Weeks (Bergey's Manual, 1957), consists of Gram-negative rods, motile by means of peritrichous flagella or non-motile, and producing yellow to brown pigments. However, this definition is not accepted by all workers. For example, Brisou, Tysset \& Vacher (1959) gave details of two flavobacteria which were motile by means of polar flagella and Ferrari \& Zannini (1958) concluded that the exclusion of the Gram-positive strains from the genus was not justified.

It is also recognized that confusion might arise between the Flavobacterium species and certain yellow-pigmented Cytophage species. Thus Stanier (1947), working with chitin-decomposing cytophagas, showed that they may simulate

* Present address : Birds Eye Foods Ltd., South Denes, Great Yarmouth, Norfolk. 
eubacteria under certain circumstances. He considered that many ill-defined eubacterial genera containing Gram-negative rods which do not form spores and are not motile, may contain cytophagas. Gibson (1955) isolated organisms from soil identical with typical cytophagas except in their failure to show gliding motility, and confirmed that the separation of cytophagas from eubacteria was under suspicion. It is known that Cytophaga species are widely distributed in marine environments (Humm, 1946; Starr \& Ordal, 1953; Bachmann, 1955; Kadota, 1956; Velankar, 1957), though isolations from fish have been very rare (Shewan \& Bain, private communication; Georgala, 1957). It seems possible that the paucity of references to Cytophaga species being found on fish may well be due to the unfavourable conditions under which they have been studied and that many organisms ascribed to the genus Flavobacterium should be ascribed to the genus Cytophaga. The purpose of the present investigation was to study marine bacteria which had been identified as flavobacteria and determine whether any had been wrongly named.

\section{METHODS}

Source of strains. With one exception all 62 strains studied had been identified as Flavobacterium species by the workers who first isolated them; the sources of these strains are given in Table 1. All 62 strains have been deposited in the National Collection of Marine Bacteria (NCMB), Torry Research Station, Aberdeen.

Organisms were maintained on slopes of sea-water agar of the following composition $(\%, w / v)$ : Lab-Lemco, 1.0; Evans peptone, 1.0; Difco agar, 1.5; aged sea water + distilled water $(3+1$, by vol.). This and all subsequent media were adjusted to $\mathrm{pH} \mathrm{7 \cdot 2-7 \cdot 3}$ unless otherwise stated. Strains were subcultured every 4 months.

Flavobacterium aquatile Windle-Taylor strain F 36, the type species, was obtained for comparative purposes; efforts to obtain Cytophaga hutchinsonii, type species, or any other authentic named species from Type Culture Collections failed.

\section{Table 1. Sources of Flavobacterium isolates}

\begin{tabular}{|c|c|c|c|}
\hline $\begin{array}{l}\text { NCMB } \\
\text { no. }\end{array}$ & $\begin{array}{l}\text { No. of } \\
\text { strains }\end{array}$ & Source & Supplier \\
\hline $244-276$ & 33 & Slime of North Sea cod & D. L. Georgala \\
\hline $\begin{array}{l}277-290 \\
\text { and } 295\end{array}$ & 15 & $\begin{array}{l}\text { Slime or gills of North Sea skate or } \\
\text { lemon sole }\end{array}$ & J. Liston \\
\hline 291-294 & 4 & $\begin{array}{l}\text { Lingcod or sea water along the } \\
\text { Pacific Coast, near Vancouver }\end{array}$ & R. A. MacLeod \\
\hline $296-300$ & $\mathbf{5}$ & Fish caught off Iceland & V. Aschehoug \\
\hline $408-411$ & 4 & $\begin{array}{l}\text { Marine mud or sea water off Cali- } \\
\text { fornian Coast }\end{array}$ & C. E. ZoBell \\
\hline 11* & 1 & Water off Florida Coast & T. J. Starr \\
\hline
\end{tabular}

Morphological and cultural characteristics. Organisms were stained by Gram's method after incubation for 4 days at $20^{\circ}$ on sea-water agar and their size was measured on similar cultures stained with methylene blue; colony appearances were noted at 5 days. Five-day cultures in sea-water broth (\%, w/v: Lab-Lemco, 1.0; 
Evans peptone, 1.0; aged sea water + distilled water, $3+1$, by vol.) incubated at $20^{\circ}$ were studied under phase contrast and the appearance of 7 -day cultures recorded. Isolates were examined for motility in sea-water tryptone water (Difco tryptone, $1.5 \%, w / v$; aged sea water + distilled water, $3+1$, by vol.). Only motile strains were stained for flagella; the technique was based on a method employing Kirkpatrick's fixative and Casares-Gil's modification of Plimmer \& Paine's flagella stain (Staining Procedures, 1947). Motile organisms were also examined with the electron microscope.

\section{Effect of environmental conditions on growth}

A standard inoculum for all tests was one loopful of a 5-day sea-water broth culture.

Temperature range of growth. The ability of the strains to grow on sea-water agar at $37^{\circ}, 30^{\circ}, 25^{\circ}, 20^{\circ}, 10^{\circ}, 5^{\circ}$ and $0^{\circ}$ was noted, the incubation periods extending from 1 to 6 weeks, depending upon the temperature of incubation.

Heat resistance. The viability of cultures grown in $3 \mathrm{ml}$. of sea-water broth for 5 days was investigated by heating for various times $\left(15,30,45,60 \mathrm{~min}\right.$.) at $45^{\circ}$ and $55^{\circ}$ before plating the heated cultures on sea-water agar and incubating at $20^{\circ}$ for 10 days. Those isolates which failed to grow at $37^{\circ}$ were investigated for ability to withstand this temperature by inoculating them on two series of sea-water agar plates. One set was incubated at $37^{\circ}$ for $24 \mathrm{hr}$. and the other for $48 \mathrm{hr}$.; both were then incubated for a further 7 days at $20^{\circ}$.

Anaerobic growth. Organisms were incubated anaerobically on sea-water agar in McIntosh \& Fildes jars for 14 days at $20^{\circ}$.

Salinity range of growth. The strains were plated on Oxoid blood agar base, with additional $\mathrm{NaCl}$ (Analar) where required, to give final $\mathrm{NaCl}$ concentrations (\%, w/v) of $0.5,2 \cdot 0,4 \cdot 0,6.0$ and 10.0 ; they were then incubated for 14 days at $20^{\circ}$.

Sensitivity to antibiotics and $a$ 'vibriostatic' compound. The isolates were tested for sensitivity to penicillin (2.5 i.u. per tablet), streptomycin (80 $\mu \mathrm{g}$.), chloramphenicol (100 $\mu$ g.), terramycin (10 $\mu$ g.) and a vibriostatic compound (2,4-diamino-6,7-diisopropylpteridine) as described by Shewan, Hodgkiss \& Liston (1954). Standard agar plates, prepared as for sea-water agar but with distilled water $+0.5 \%(\mathrm{w} / \mathrm{v})$ $\mathrm{NaCl}$ were used, since sensitivity to antibiotics is markedly different on sea-water agar, the higher salt concentration either masking the inhibitory effects of the antibiotics or stimulating bacterial growth.

\section{Physiological tests}

The same standard inoculum was used as previously. All the media were incubated at $20^{\circ}$.

Gelatin liquefaction. Nutrient gelatin medium (\%, w/v: Lab-Lemco, 1.0; Evans peptone, 1.0; $\mathrm{NaCl}, 2 \cdot 0$ : Oxoid gelatin, 12.0) was inoculated and incubated for 6 weeks, the appearance and extent of liquefaction being noted at regular intervals.

Action on litmus milk. The cultures were incubated in litmus milk for 6 weeks, changes in appearance being noted at regular intervals.

Reduction of nitrate to nitrite. Nitrite was tested for by the Griess-Ilosvay reagents after incubation for 10 days in nitrate broth $(\%, \mathrm{w} / \mathrm{v}$ : Lab-Lemco, 1.0; 
Evans peptone, $\left.1 \cdot 0 ; \mathrm{NaCl}, 2 \cdot 0 ; \mathrm{KNO}_{3}, 0 \cdot 1\right)$. Powdered zinc was used to test for false negatives.

Ammonia production was tested for by Nessler's reagent after incubation for 10 days in sea-water peptone water (Evans peptone, 1.0\%, w/v; aged sea water + distilled water, $3+1$, by vol.).

Hydrogen sulphide formation was detected with strips of filter paper impregnated with lead acetate on cultures incubated for 14 days in sea-water broth containing $0.01 \%(w / v)$ cysteine hydrochloride (final pH 7.6).

Indole formation was determined by Ehrlich's reagent after xylene extraction of cultures incubated for 10 days in sea-water tryptone water.

Hydrolysis of urea. Cultures were incubated for 14 days on slopes of Christensen agar (1946), modified by the inclusion of $(\%, \mathrm{w} / \mathrm{v}): \mathrm{KH}_{2} \mathrm{PO}_{4}, 0.05 ; \mathrm{K}_{2} \mathrm{HPO}_{4}, 0.05$; Oxoid yeast extract, 0.01; bromthymol blue, 0.003; aged sea water + distilled water $(3+1$, by vol.). To ensure that the alkalinity produced was due to urea hydrolysis a control medium without urea was inoculated with the urease-positive strains. Only those strains which gave a markedly more alkaline reaction in the urea medium were considered to be true positives.

Trimethylamine oxide reduction. Cultures were incubated for 14 days in Wood \& Baird's medium (1943) modified by the use of aged sea water + distilled water $(3+1$, by vol.). The presence of trimethylamine was then tested for according to the method given in Topley and Wilson's Principles (1955).

Production of acid from carbohydrate. Cultures were incubated for 28 days in a medium composed of: Evans peptone, 0.5\% (w/v); $\mathrm{NaCl}, 2.0 \%(\mathrm{w} / \mathrm{v})$; Andrade's indicator, $1.0 \%(\mathrm{v} / \mathrm{v})$; test carbohydrate, $1.0 \%(\mathrm{w} / \mathrm{v})$. Each culture was examined regularly for acid and gas production. The following carbohydrates were used: arabinose, xylose, rhamnose, glucose, fructose, mannose, galactose, sucrose, maltose, lactose, trehalose, raffinose, starch, inulin, mannitol, dulcitol, sorbitol, inositol, salicin.

Glucose utilization. The method of Hugh \& Leifson (1953) was used to determine whether glucose was used oxidatively or fermentatively.

Production of 2-ketogluconic acid. Cultures were incubated for 7 days in Paton's medium (1959). All the strains which grew in this medium were examined for 2-ketogluconic acid production by using the reagent of Hough, Jones \& Wadman (1950).

Starch hydrolysis. After incubation of the strains in the starch medium for 28 days (see Production of acid from carbohydrates) those cultures which showed no acid production were tested with a drop of iodine solution for the presence of starch breakdown products.

Tributyrin hydrolysis. Cultures were incubated and examined on Oxoid tributyrin agar for 14 days.

Growth in Koser's citrate medium was read after incubation for 7 days; strains which showed growth after two serial subcultures were recorded as positive.

Voges-Proskauer and methyl red tests. Cultures were tested after incubation for 10 days in glucose phosphate broth by Barritt's modification for acetylmethylcarbinol (Topley and Wilson's Principles, 1955).

Digestion of chitin. Chitin, prepared from crab shells by the method of Benton (1935), was incorporated in the following medium $(\%, w / v)$ : chitin, 3.5 ; glucose, 
$0 \cdot 1$; Evans peptone, $0 \cdot 1 ; \mathrm{K}_{2} \mathrm{HPO}_{4}, 0.005 ;$ Difco agar, 1.5 ; aged sea water + distilled water $(3+1$, by vol.). Cultures were incubated for 6 weeks and examined at regular intervals.

Decomposition of cellulose. Cultures were incubated for 6 weeks on a medium consisting of $(\%, w / v)$ : Whatman powdered cellulose, 5.0; Oxoid yeast extract, 0.02 ; Evans peptone, $0.2 ; \mathrm{KH}_{2} \mathrm{PO}_{4}, 0.1 ; \mathrm{FePO}_{4} .2 \mathrm{H}_{2} \mathrm{O}$, trace; Difco agar, 1.5; aged sea water + distilled water $(3+1$, by vol. $)$. The plates were examined at regular intervals.

Blood agar. The cultures were incubated on horse-blood agar for 14 days and examined regularly for growth and haemolysis.

Actomyosin agar. Actomyosin, prepared from fish muscle by the method of Connell (1958), was incorporated in normal sea-water agar at $1.0 \%(w / v)$, giving an opaque medium. The cultures were incubated for 6 weeks and examined regularly for actomyosin breakdown as indicated by clear zones.

Catalase and oxidase formation. Catalase was tested for by adding hydrogen peroxide (20 vol.) to 3-day cultures on sea-water agar; for oxidase formation the method of Kovacs (1956) was used on similar cultures.

\section{Nutrition}

Preparation and cultivation of inoculum. The standard inoculum for all tests was one loopful of a 5-day sea-water broth culture. Media were incubated for 7 days at $20^{\circ}$ and only those strains which showed visible growth after two serial subcultures were recorded as positive.

Media preparation. The compositions of the media used are given in Table 2. All media were adjusted to $\mathrm{pH} \mathbf{7 \cdot 2 - 7 \cdot 3}$ and sterilized by intermittent steaming.

\section{Swarming}

A preliminary study with different concentrations of agar and peptone indicated that swarming was most markedly dependent on the peptone concentration with $2 \%(w / v)$ agar. Therefore the basal medium consisted of $(\%, w / v):$ Lab-Lemco, $0 \cdot 1$; Difco agar, $2 \cdot 0$; aged sea water + distilled water $(3+1$, by vol. $)$. To this were added different amounts of Evans peptone as follows $(\%, w / v): 8 \cdot 0,4 \cdot 0,1 \cdot 0,0 \cdot 25$, 0.05 and 0.01 . The Lab-Lemco was included to stimulate growth; without it colonies were so minute on the lower peptone concentrations as to be impossible to be examined visually for swarming. The Lab-Lemco appeared to exert no inhibiting effect on swarming. After the plates had been poured with these media they were dried for $30 \mathrm{~min}$. at $55^{\circ}$ and then stored overnight at $20^{\circ}$, before inoculation with the standard inoculum. The plates were incubated at $20^{\circ}$ for 10 days when colony appearance and any indication of swarming was noted. Flavobacterium aquatile F 36 was plated on distilled water media containing $0.5 \%(w / v) ~ N a C l$ and the lowest three peptone concentrations. 


\section{Cell-wall studies}

Staining of cell walls. Cell walls were stained by using the phosphomolybdic acid mordant technique recommended by Hale (1953).

Cell-reall analysis. Strains NCMB 244, 249, 251 and 253 were taken as representatives of Groups 1-4 (see Results). Flavobacterium aquatile F 36 and strain NCMB 11 were used as controls for the genera Flavobacterium and Cytophaga, respectively.

Table 2. Composition of media

\begin{tabular}{|c|c|c|c|c|c|c|c|}
\hline & \multicolumn{6}{|c|}{ No. medium } \\
\hline & & $\begin{array}{c}1 \\
\text { Basal } \\
\text { medium }\end{array}$ & $\begin{array}{l}\mathbf{2} \\
\text { Amino } \\
\text { acid } \\
\text { medium }\end{array}$ & $\begin{array}{c}3 \\
\text { Growth } \\
\text { factor } \\
\text { medium }\end{array}$ & $\begin{array}{c}4 \\
\text { Growth } \\
\text { factor } \\
\text { medium }\end{array}$ & $\begin{array}{c}\quad \mathbf{5} \\
\text { Purine+ } \\
\text { pyrimidine } \\
\text { medium }\end{array}$ & $\begin{array}{l}\quad 6 \\
\text { Peptone } \\
\text { medium* }\end{array}$ \\
\hline \multicolumn{8}{|c|}{ Basal constituents (g./1.) } \\
\hline Glucose & 5 & + & + & + & + & + & + \\
\hline $\mathrm{NaCl}$ & 25 & + & + & + & + & + & + \\
\hline $\mathrm{K}_{2} \mathrm{HPO}_{4}$ & 1 & + & + & + & + & + & + \\
\hline $\mathrm{MgSO}_{4} \cdot 7 \mathrm{H}_{2} \mathrm{O}$ & 1 & + & + & + & + & + & + \\
\hline$\left(\mathrm{NH}_{4}\right)_{2} \mathrm{SO}_{4}$ & $\mathbf{2}$ & + & + & + & + & + & + \\
\hline $\mathrm{CaCl}_{2}$ (anhyd.) & trace & + & + & + & + & + & + \\
\hline $\mathrm{FeCl}_{3} \cdot 6 \mathrm{H}_{2} \mathrm{O}$ & trace & + & + & + & + & + & + \\
\hline $\begin{array}{l}\text { Amino acids, eacl } \\
100 \text { mg./l. : glyci } \\
\text { alanine, DL-serin } \\
\text { cysteine, DL-thre } \\
\text { DL-methionine, } \\
\text { DL-leucine, DL-p } \\
\text { alanine, DL-tyro } \\
\text { tryptophan, L-hi } \\
\text { HCl, DL-ornithin } \\
\text { L-arginine, DL-gl } \\
\text { acid, DL-aspartic } \\
\text { DL-proline }\end{array}$ & $\begin{array}{l}\text { DL- } \\
\text { L- } \\
\text { ine, } \\
\text { aline, } \\
\text { yl- } \\
\text {, DL- } \\
\text { dine } \\
\text { IBr, } \\
\text { imic } \\
\text { id, }\end{array}$ & - & + & + & + & + & + \\
\hline $\begin{array}{l}\text { Growth factors }(\mu \\
p \text {-aminobenzoic } \\
\text { nicotinic acid }(5 \\
\text { thenic acid }(500) \\
\text { doxine HCl }(200 \\
\text { HCl }(500), \text { ribof }\end{array}$ & $\left.\begin{array}{l}\text { l.) } \\
\text { d (100), } \\
\text { panto- } \\
\text { yri- } \\
\text { hiamine } \\
\text { n (100) }\end{array}\right\}$ & - & 一 & + & + & + & + \\
\hline $\begin{array}{l}\text { Folic acid (1), bio } \\
\beta \text {-alanine }(500), \\
\text { vitamin } B_{12}(0.5)\end{array}$ & (2), & - & - & 一 & + & + & + \\
\hline $\begin{array}{l}\text { Purines }+ \text { pyrimid } \\
\text { each at } \mathbf{2 0 0} \mathrm{mg} / \\
\text { adenine, guanine }\end{array}$ & $\left.\begin{array}{l}\mathbf{s}, \\
\text { iracil, } \\
\text { anthine }\end{array}\right\}$ & - & - & - & - & + & + \\
\hline Evans peptone (1 & & - & - & - & - & - & + \\
\hline
\end{tabular}

* Filtered sea water was added to the peptone medium (6), in the ratio medium (6): sea water (3:1), giving an additional medium (7).

+ , Constituent(s) included in medium.

- , Constituent(s) absent.

Culture media. The same method was used for all isolates except that $F$. aquatile was grown in standard nutrient broth whereas the marine bacteria were grown in sea-water broth. Three hundred ml. amounts of media were used in 11 . conical flasks. After inoculation, the flasks were shaken for 3 days on a Townson and Mercer 
'lateral' shaker at a speed of 80-90 throws/min., the incubation temperature being $20^{\circ}$.

Preparation and hydrolysis of cell-wall suspensions. The technique used was that of Cummins \& Harris (1956).

Chromatography. For amino acids and hexosamines, two-dimensional ascending chromatograms on Whatman No. 1 paper were used. Less cell-wall material was available with strains NCMB 244 and 249 because of the comparative difficulty in centrifuging them; this effect was frequently noticed when centrifuging marine organisms grown in sea-water based media. Phenol + water $(80+20$, by vol. $)$ in an ammoniacal atmosphere was used as the first solvent and lutidine + collidine + water $(150+100+120$, by vol.) as the second. The spots were located by spraying with ninhydrin solution.

Sugars were detected by descending chromatography on Whatman No. 1 paper with ethyl acetate + pyridine + water $(120+50+40$, by vol. $)$ as solvent and aniline hydrogen phthalate (Partridge, 1949) as locating agent; because of similar $R_{F}$ values arabinose and mannose were distinguished by placing the chromatogram under the ultraviolet light, when the arabinose fluoresced and the mannose appeared as a brown spot.

\section{RESULTS}

Sixty of the strains studied were Gram-negative, of which 54 were non-motile and 6 motile; the remaining 2 strains were Gram-positive and non-motile. An analysis of the results obtained with the 54 non-motile Gram-negative bacteria clearly suggests that many of these organisms could be placed in one of the following 4 main groups.

Group 1. Usually small slender rods producing pale yellow or yellow-green pigmented colonies on agar. Growth range $0^{\circ}-30^{\circ}$. Resistant to $45^{\circ}$ for $1 \mathrm{hr}$. and to $37^{\circ}$ for $48 \mathrm{hr}$. Markedly sensitive to penicillin and to the 'vibriostatic' compound. Gelatin liquefied slowly, if at all; litmus milk unchanged. Ammonia not formed from peptone. Carbohydrates attacked with production of acid; lactose and starch not attacked. Generally complex nutritional requirements, failing to grow on defined media. This group is composed of strains NсмB 244-6, 248, 252, 255, 258-9, 261, 263, 273, 281, 295 and 298.

Group 2. Usually short, oval rods but some pleomorphic. Deep yellow or orangeyellow pigmented colonies. No growth at $30^{\circ}$. Not resistant to $45^{\circ}$ for $1 \mathrm{hr}$. or to $37^{\circ}$ for $24 \mathrm{hr}$. Gelatin liquefied. Litmus milk reduced, with peptonization (NCMB $267,270-1$ ) or with an alkaline reaction ( hydrates not attacked and starch not hydrolysed. Complex nutritional requirements but grow on defined media. No growth on blood agar. This group is composed of strains NCMB 250-1, 260, 262, 264-5, 267-72, 276, 284 and 289.

Group 3. Short oval or pleomorphic rods. Deep yellow or orange-yellow pigmented colonies. No growth at $30^{\circ}$. Not resistant to $45^{\circ}$ for $1 \mathrm{hr}$. but viable after $48 \mathrm{hr}$. at $37^{\circ}$. Gelatin not liquefied. Litmus milk reduced. Most carbohydrates not attacked, but starch hydrolysed. Nutritional requirements not complex and growth factors not required. This group is composed of strains NCMB 249, 254 and 287.

Group 4. Long slender rods, pleomorphic. Pale yellow or yellow-green pigmented colonies. Not resistant to $45^{\circ}$ for $1 \mathrm{hr}$. but viable after $48 \mathrm{hr}$. at $37^{\circ}$. Litmus milk 
reduced. Carbohydrates attacked, including lactose and starch, with production of acid. Complex nutritional requirements but will grow on defined media. This group is composed of strains NCMB 247, 253, 256-7, 275 and 285.

Thirty-eight isolates are included in the 4 groups above. Of the remainder, strain мсMв 11 is confirmed as a Cytophaga species and strain NCMB 292 is also considered to be a typical cytophaga. Both these organisms swarmed readily on normal media and, in addition, had the following properties in common with the genus Cytophaga (Bergey's Manual, 1957): (1) morphology, being long, slender rods with axes straight, bent, $U$ - or S-shaped; (2) absence of microcysts; (3) yellow pigmented spreading colonies typical of cytophagas. Other properties these organisms had in common were: (4) oxidase-positive; (5) liquefaction of gelatin; (6) resistance to $45^{\circ}$ for $1 \mathrm{hr}$; (7) viability after $48 \mathrm{hr}$. at $37^{\circ}$. Neither is described in the genus Cytophaga in Bergey's Manual (1957).

The remaining 14 Gram-negative non-motile strains cannot be justifiably placed in any of the above groups. An analysis of their properties suggests that further small groups may be formed but these groups would be less rigid in their definition than those already described. Three strains, мсмв 282, 291 and 408, appear to merit individual species rank, each being markedly different from any other organisms.

The 6 Gram-negative motile bacteria formed a heterogeneous collection as follows.

(1) Strain Nсмв 283 is considered to be a Vibrio species because it: $(a)$ is motile with a single polar flagellum; $(b)$ produces acid in glucose; $(c)$ is fermentative in Hugh and Leifson's medium; $(d)$ is sensitive to the vibriostatic compound.

(2) Strain лсмв 286 is considered to be a pigmented Pseudomonas species, failing to produce acid from carbohydrates, because it: $(a)$ is motile with polar flagella; $(b)$ reduces nitrate to ammonia or nitrogen; $(c)$ is oxidase-positive; $(d)$ reduces trimethylamine oxide. However, it is penicillin-sensitive, a rare property in the genus.

(3) Strain NCMB 294 is considered likely to be a pigmented Pseudomonas species, failing to produce acid from carbohydrates, because it is: (a) motile with polar flagella; $(b)$ oxidase-positive; $(c)$ insensitive to penicillin.

(4) Strain NCMB 297 is a pink-pigmented peritrichously flagellate organism producing acid from several carbohydrates including glucose and lactose; it cannot be satisfactorily ascribed to any genus.

(5) Strains NCMB 296 and 300 are grouped together because they have many properties in common including: $(a)$ yellow-green pigmented colonies; $(b)$ peritrichous flagella; $(c)$ resistance to $45^{\circ}$ for $1 \mathrm{hr}$; ; $(d)$ strong hydrogen sulphide production; $(e)$ strongly urease-positive; $(f)$ reduction of nitrate to nitrite; $(g)$ no liquefaction of gelatin; $(h)$ growth in basal medium; $(i)$ production of 2-ketogluconic acid; ( $j$ ) hydrolysis of tributyrin. According to Bergey's Manual (1957) they would be identified as Flavobacterium species but they are not similar to any species listed.

The Gram-positive strains, мсмв 280 and 299, are from their morphology, colony appearance and biochemical reactions, typical Corynebacterium species.

The characters distinguishing many of the strains have been mentioned already; detailed properties of individual strains are omitted for brevity but the principal results are summarized below. 


\section{Morphological and cultural characteristics}

Gram reaction. With the exception of the two corynebacteria, all organisms were Gram-negative rods varying from long slender forms (length, $5.0 \mu$; width, $0 \cdot 4 \mu$ ) to short stout 'coccobacilli' (length, $1 \cdot 0 \mu$; width, $0 \cdot 6 \mu$ ).

Morphology under phase contrast. The Gram-negative bacteria again varied from long slender rods to short stout rods, though there was a marked tendency for longer and more slender rods to develop in liquid media than on solid media.

Motility and flagella staining. Of the 6 motile bacteria, peritrichous flagella were demonstrated for 3 strains and polar flagella (1-2/rod) for 3 (see above).

Colony characteristics. Colony pigmentation of the Gram-negative non-motile bacteria ranged from deep yellow or orange-yellow to pale yellow or yellow-green. The bacteria comprising each of the 4 main groups above had similarly pigmented colonies. The typical appearance of colonies at 5 days was: yellow pigmentation, 1.5-0.5 mm. in diameter, circular, convex, surface smooth and shiny, entire edge, translucent by transmitted light. The cytophaga, мсмв 292, was an agar liquefier.

Appearance in sea-water broth. Almost all isolates grew slowly in sea-water broth, visible turbidity appearing in 2 or 3 days. Nearly all isolates gave a moderate degree of turbidity throughout the medium; the presence or absence of surface growth and deposits were variable characters.

\section{Effect of environmental conditions on growth}

Temperature range of growth. Forty-three isolates grew in either the $0^{\circ}$ to $30^{\circ}$, or $0^{\circ}$ to $25^{\circ}$ temperature ranges; only 9 did not grow below $10^{\circ}$. Only strains лсмв 300 and 411, the cytophaga мсмв 11, and the corynebacterium мсмв 280 , grow at $37^{\circ}$.

Heat resistance. Thirty-nine isolates, including all members of groups 2,3 and 4 , were not resistant to $45^{\circ}$ for $1 \mathrm{hr}$., and of these, 28 were unable to withstand $45^{\circ}$ for $30 \mathrm{~min}$. In fact 13 isolates, mainly members of group 2, were not resistant to $45^{\circ}$ for $15 \mathrm{~min}$. Of the remaining 23 organisms only two (NCMB 411 ; the corynebacterium NCMB 280) were resistant to $55^{\circ}$ for $30 \mathrm{~min}$. Of the 58 organisms examined, 36 grew normally after $24 \mathrm{hr}$. at $37^{\circ}$, this number decreasing to 27 after $48 \mathrm{hr}$. Not unexpectedly those strains which showed loss of viability after $24 \mathrm{hr}$. at $37^{\circ}$ were least resistant to higher temperatures and those which survived after $48 \mathrm{hr}$. at $37^{\circ}$ were all able to withstand $45^{\circ}$ for $1 \mathrm{hr}$.

Anaerobic growth. Only four organisms, ксмв 263, 268, 279 and the vibrio NCMB 283, grew anaerobically, producing only slight growth.

Salinity range of growth. Fifty-one strains grew in $6 \%(\mathrm{w} / \mathrm{v}) \mathrm{NaCl}$ and 6 of these (NCMB 289, 296, 299, 409, the corynebacterium NCMB 299, and the unclassified strain NCMB 297) grew in $10 \%(\mathrm{w} / \mathrm{v}) \mathrm{NaCl}$; with the majority growth was better on the lower concentrations but at $6 \% \mathrm{NaCl}$ the growth was usually more than scanty. Nine strains did not grow at a concentration greater than $4 \%(\mathrm{w} / \mathrm{v})$ $\mathrm{NaCl}$ and two (NCMB 291, 408) only tolerated $2 \%(\mathrm{w} / \mathrm{v}) \mathrm{NaCl}$. A number of isolates NCMB 266, 279, 285, 289, 290, 293; the cytophagas NCMB 11, 292) showed a marked decrease of growth at the lowest concentration $(0.5 \%, \mathrm{w} / \mathrm{v}, \mathrm{NaCl})$.

Sensitivity to antibiotics and $a$ 'vibriostatic' compound. Fifty-seven organisms 
were markedly sensitive to chloramphenicol (radius of inhibited growth $>10 \mathrm{~mm}$.), the exceptions (NCMB 262, 273, 411, the vibrio NCMB 283 and the unclassified strain мсмв 297) being sensitive to a lesser degree. Fifty-four isolates were sensitive to streptomycin and 36 to penicillin; the organisms comprising groups 1 and 3 were almost all markedly sensitive to penicillin. Twenty-one isolates were sensitive to the vibriostatic compound, 14 being group 1 strains, but these isolates were non-motile and would not be considered as Vibrio species (Bergey's Manual, 1957).

\section{Physiological features}

Gelatin liquefaction. Forty-two (67\%) isolates were slow gelatin liquefiers, the reactions ranging from complete liquefaction in 14 days to slight liquefaction in 6 weeks. With one exception the liquefaction was saccate or infundibuliform; the exception, strain NсMB 292, was stratiform. Seventeen strains did not liquefy gelatin and three did not grow under the test conditions (see Table 3). These results confirm those of Gary (1950) who, in a study of 30 non-marine flavobacteria, found that $83 \%$ liquefied gelatin. An analysis of the properties of those Flavobacterium species listed in Bergey's Manual (1957), which had been isolated from marine sources ('marine flavobacteria') showed $88 \%$ to be gelatin liquefiers. Ferrari \& Zannini (1958), with 46 strains considered by them to be flavobacteria, found that $17 \%$ liquefied gelatin. Several representative cultures received from these authors had a morphology and colony appearance typical of Corynebacterium species (e.g. NсMB 644, 667). It seems almost certain therefore that they were studying a heterogeneous collection of bacteria and for this reason their results will not be discussed further.

Action on litmus milk. Forty-two (67\%) strains produced a variety of changes in litmus milk; in no case were these rapid. The most common action was the reduction of litmus frequently associated with either peptonization or an acid or alkaline reaction; 8 strains produced an alkaline reaction with no other change. With the exception of group 1 strains, which failed to change the medium, groups 2 , 3 and 4 produced no characteristic reactions (see Table 3). Of the bacteria examined by Gary (1950) $49 \%$ produced changes in litmus milk and $56 \%$ of the marine flavobacteria in Bergey's Manual (1957) are listed as producing changes.

Reduction of nitrate to nitrite. Only 5 isolates (NCMB 280, 283, 286, 296, 300) reduced nitrate to nitrite, strain мсмв 286 continuing the reduction to ammonia or nitrogen gas. It should be noted that only two of these isolates are flavobacteria and these are motile (see Discussion). Gary (1950) found only $13 \%$ of his flavobacteria to be nitrate reducers, whereas $47 \%$ of the marine flavobacteria in Bergey's Manual (1957) are listed as nitrate-reducing species.

Ammonia production. Forty-two $(67 \%)$ organisms gave a positive ammonia reaction but only 6 , including the group 3 isolates, were strongly positive (see Table 3). Of the marine flavobacteria in Bergey's Manual (1957), $75 \%$ are given as positive.

Hydrogen sulphide formation. Fifty-two $(\mathbf{8 4} \%)$ of the isolates produced hydrogen sulphide (see Table 3). These results contradict those of Gary (1950), who found that none of his flavobacteria produced hydrogen sulphide, and those of Bergey's Manual (1957) which lists $33 \%$ of the marine flavobacteria as positive.

Indole formation. None of the organisms gave an indole-positive reaction. All 


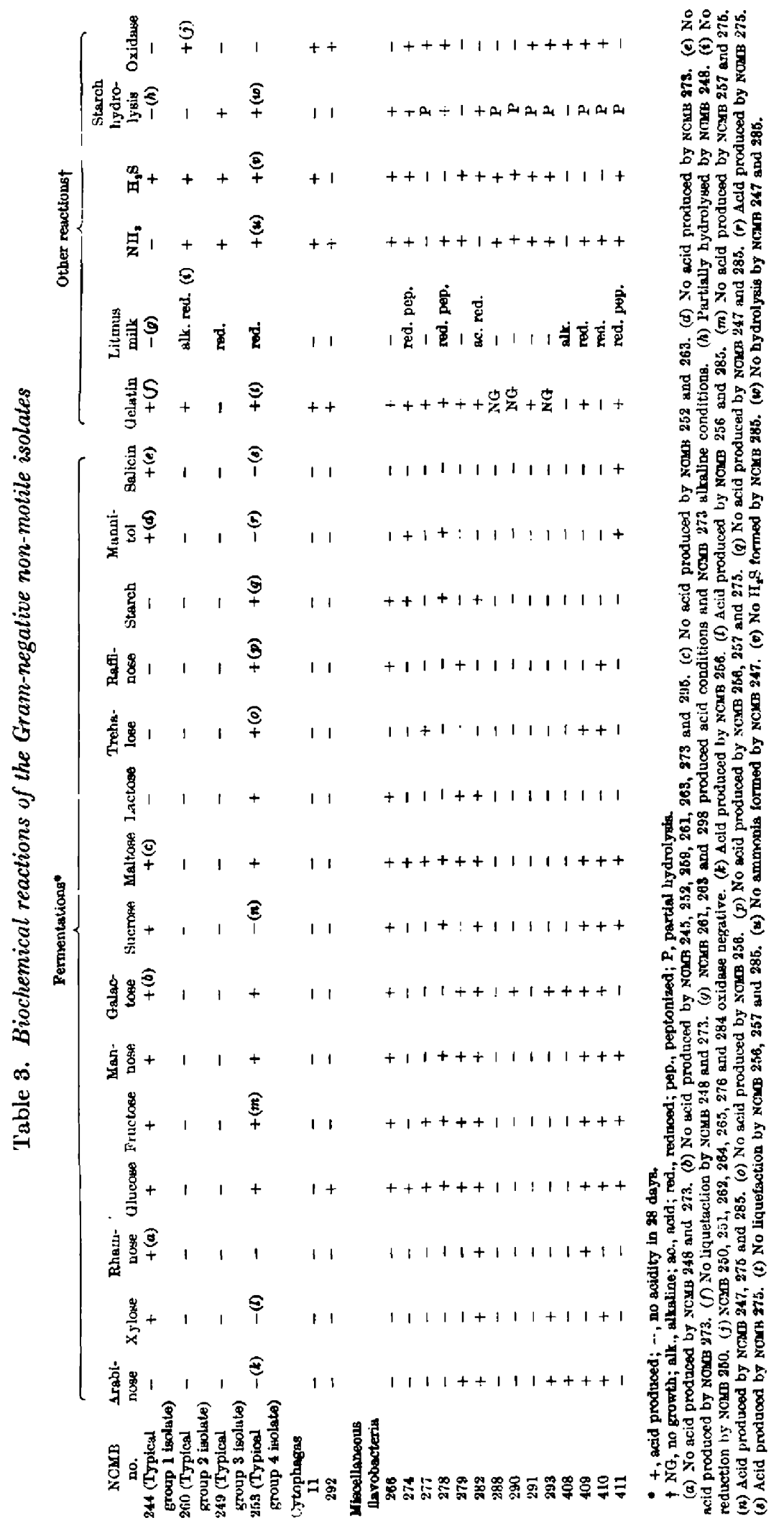


marine flavobacteria in Bergey's Manual (1957) are said to be negative, whereas Gary (1950) found $17 \%$ of his flavobacteria to be positive.

Hydrolysis of urea. Only 6 organisms ( urea; of these only Nсмв 295 is a member of one of the main groups.

Trimethylamine oxide reduction. Only лсмв 286, Pseudomonas species, was found to reduce trimethylamine oxide.

Production of acid from carbohydrates. Thirty-six (58\%) isolates produced acid only from one or more carbohydrates. Acid production was not generally noted until after incubation for 1 week and only slight to moderate amounts were then present (see Table 3); of the carbohydrates not listed, inulin was attacked with acid formation by 4 strains (NCMB 247, 266, 297, 410), sorbitol by one strain (NCMB 244), whilst dulcitol and inositol were not attacked by any of the isolates. Glucose was the most commonly attacked carbohydrate though three isolates which dissimilated galactose with acid production failed to attack glucose. Gary (1950) found the formation of acid from glucose, sucrose, maltose, lactose and mannitol varied between 10 and $23 \%$; a few flavobacteria formed acid and gas from glucose and sucrose but Gary considered that the 'fermentative' strains should be excluded from the genus. Little information on carbohydrate dissimilation by the marine flavobacteria is given in Bergey's Manual (1957) except that $70 \%$ formed acid from glucose.

Glucose utilization. Only 2 strains ( (NCMB 278, 282-3) fermentative. Seventeen isolates, including 13 from group 2, produced an alkaline reaction in the aerobic tube only, and 31 organisms did not change the medium; the remaining 9 isolates did not grow. Thirty-three organisms formed acid from glucose and yet only 5 gave a positive result in Hugh \& Leifson's medium; the remaining 28 organisms either did not change the medium or did not grow. With the strains which failed to produce any change the growth was frequently very slight; this may account in part for these unexpected results. Also the strains were relatively late and weak acid producers and the indicator may not have been sufficiently sensitive. Acid production was more marked from fructose than from glucose, and fructose was therefore substituted for glucose in the medium. Acidproducing bacteria were examined but growth was again slight and no $\mathrm{pH}$ change was noted. Thus it appeared that these anomalous results were not due to the insensitivity of the indicator but were possibly due to the indicator exerting an inhibitory effect. To confirm this Andrade's indicator was used as an alternative. Though less sensitive than bromthymol blue a definite acid reaction was obtained with a number of organisms which previously had shown no change. However a few strains did not grow and others showed only slight growth with no $\mathrm{pH}$ change and anomalous results remained.

Production of 2-ketogluconic acid. Only 3 isolates grew in the gluconate medium and of these, NCMB 296 and 300 (both motile flavobacteria; see Discussion) gave a positive reaction. No flavobacteria have been reported to produce 2-ketogluconic acid.

Starch hydrolysis. Thirteen (21\%) isolates hydrolysed starch and of these, 9 continued the breakdown to acid; also, 11 other strains partially hydrolysed starch (see Table 3). Gary (1950) found that $40 \%$ of his flavobacteria hydrolysed starch.

Tributyrin hydrolysis. Only 18 isolates grew on the test medium and 15 of these 
hydrolysed tributyrin, including 6 isolates from group 1, one from group 3 , the cytophaga NCMB 11, and NСмB 408, 409 and 411; the remainder consisted of the motile strains, NCMB 296 and 300 and the corynebacteria.

Growth in Koser's citrate medium. Only the Corynebaterium species мсмв 299, the unidentified species мсмв 297, and the motile flavobacterium мсмв 296, utilized citrate; Gary (1950) found that $43 \%$ of his flavobacteria grew in citrate.

Voges-Proskauer and methyl red tests. None of the strains was Voges-Proskauerpositive and only 2 (the vibrio and the unidentified species) were methyl redpositive; 12 isolates did not grow.

Digestion of chitin. Of the 29 isolates which grew in the medium containing chitin none digested this substrate.

Decomposition of cellulose. All isolates grew on the test medium but none appeared to decompose the cellulose.

Blood agar. Only 32 isolates grew on blood agar; none haemolysed the blood.

Actomyosin agar. All the isolates grew on this medium but none attacked the actomyosin.

Catalase and oxidase formation. All isolates were catalase-positive and 21 were oxidase-positive (see Table 3).

Table 4. Nutritional requirements

\begin{tabular}{|c|c|c|}
\hline Medium & $\begin{array}{l}\text { No. } \\
\text { strains } \\
\text { first } \\
\text { showing } \\
\text { growth }\end{array}$ & NCMB number \\
\hline Basal medium 1 & $\mathbf{2}$ & 296, 300 \\
\hline Amino acid medium 2 & 10 & $\begin{array}{l}249,254,269,280, \\
286,287,294,11 \text {, } \\
409,411\end{array}$ \\
\hline Growth factor medium 3 & $\cdot 6$ & $\begin{array}{l}273,275,281,284 \\
292,297\end{array}$ \\
\hline Growth factor medium 4 & 18 & $\begin{array}{l}247,250,251,253, \\
256,257,262,264 \\
265,267,270,271 \\
272,276,278,282 \\
299,408\end{array}$ \\
\hline Purine + pyrimidine medium 5 & $\mathbf{3}$ & $260,268,274$ \\
\hline Peptone medium 6* & 20 & $\begin{array}{c}244,245,246,248, \\
252,255,258,259 \\
261,263,266,279 \\
288,289,290,291 \\
293,295,298,410\end{array}$ \\
\hline
\end{tabular}

* Strain NCMB 285 only grew on the addition of sea water to this medium. Strains NCMB 277 and 283 failed to grow in any of the test media.

\section{Nutrition}

The nutritional requirements of the isolates are given in Table 4, which shows the generally complex requirements of the majority of isolates tested. Only the motile flavobacteria (NCMB 296, 300) grew in the basal medium. The 10 isolates which grew in the amino acid medium included all group 3 strains, the two Pseudomonas 
species, one each from groups 1 and 2, and the cytophaga NCMB 11; those which grew in the growth factor medium no. 3 included the cytophaga мсмв 292, two group 1 organisms, one each from groups 2 and 4 and the unidentified species NCMB 297. Of the 18 isolates which grew in the growth factor medium no. 4, 10 were group 2 strains and 4 group 4 strains. Of the 20 isolates which required peptone, 12 were group 1 organisms. The isolate NCMB 285 which only grew on the addition of sea water also failed to grow in distilled water nutrient broth and it can only be assumed that it had complex ionic requirements. The two organisms which did not grow in any test media grew in sea-water peptone water; this anomalous result may have been due to antagonism between nutrients at the concentrations supplied.

The results are generally in agreement with the few publications on this topic. No previous paper has dealt specifically with the nutrition of marine flavobacteria. It is apparent from two contributions on non-marine flavobacteria that they have complex nutritional requirements (Prince, Beck, Cleverdon \& Kulp, 1954; Prince \& Cleverdon, 1955). In a study of the nutrition and metabolism of marine bacteria, MacLeod, Onofrey \& Norris (1954) found the flavobacteria to have diverse requirements: one strain required unknown growth factors; three required amino acid mixtures; one strain had simple requirements. Weeks \& Beck (1960) found Flavobacterium aquatile to require only thiamine as a growth factor, though an enzymic hydrolysate of casein, glucose and inorganic salts were also supplied.

\section{Swarming}

The cytophagas NCMB 11 and 292, all 6 group 4 isolates and 12 of the 14 group 1 isolates all produced spreading colonies in one or more of the media used. A clear gradation was seen in the colonies developed by the strains which showed swarming tendencies. When grown on high peptone concentrations the colonies, even of the Cytophaga species, were discrete and corresponded to those formed by typical Flavobacterium species. A tendency for colonies to spread became more evident with decreasing peptone concentrations; strains frequently produced 'intermediate' colonies which had raised centres and flattened peripheries but did not exhibit true swarming. In the lowest peptone concentration swarming was less in evidence, the colonies being minute because of the extreme lack of available nutrients.

Normal sea-water agar contained $1.0 \%(\mathrm{w} / \mathrm{v})$ peptone with $1.5 \%(\mathrm{w} / \mathrm{v})$ agar and on this medium 4 isolates developed spreading colonies after incubation for 10 days; with $2.0 \%(\mathrm{w} / \mathrm{v})$ agar this number was increased to 6 isolates. When the peptone concentration was lowered to $0 \cdot 25 \%(\mathrm{w} / \mathrm{v})$ swarming was observed with 15 isolates and a further 3 isolates gave rise to 'intermediate' colonies. These 18 isolates swarmed readily at the lower peptone concentrations. Two isolates only developed spreading colonies on $0.01 \%(w / v)$ peptone. By increasing the peptone concentration to $4 \%(\mathrm{w} / \mathrm{v})$ only the two cytophagas NCMB 11 and 292 swarmed; at $8 \%(\mathrm{w} / \mathrm{v})$ peptone, swarming was completely inhibited. Isolates which failed to form spreading colonies on any of the media showed only a progressive diminution in colony size with lower peptone concentrations. Flavobacterium aquatile did not swarm on any of the test media.

When the swarming edges of colonies of the cytophagas NCMB 11 and 292 were observed microscopically, gliding motility was seen distinctly only on 1 and $0.25 \%$ $(w / v)$ peptone agar; gliding motility was not seen with colonies of these organisms 

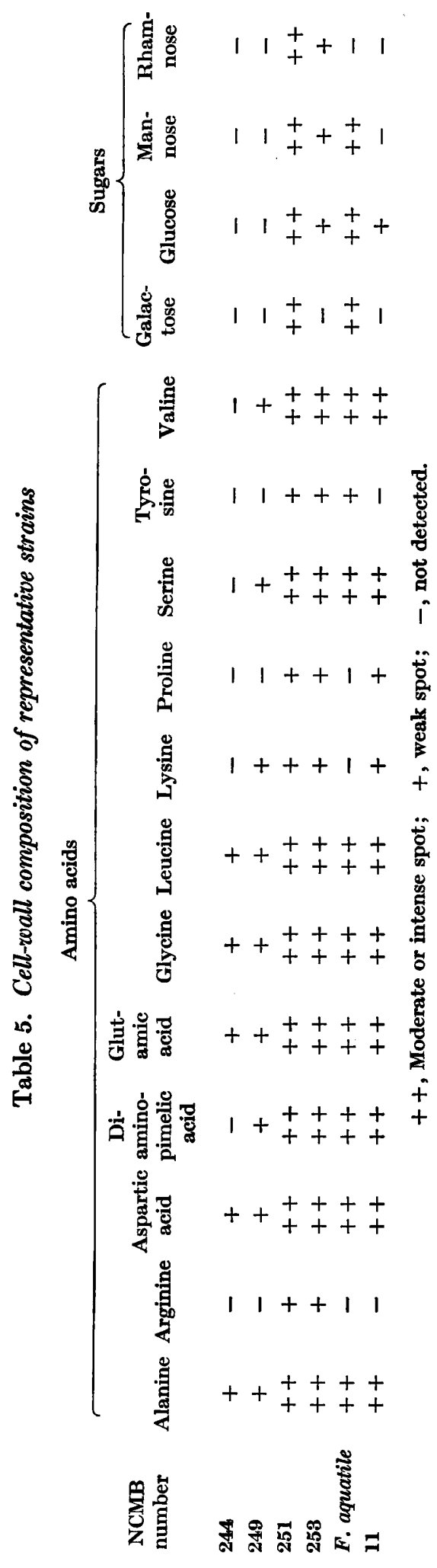
on 4 and $8 \%(w / v)$ peptone agar. A gradation in degree of motility corresponding to the colony form was thus suggested, confirming that gliding motility was characterized macroscopically by spreading growth of the colony. Distinct gliding motility was not observed microscopically with any other isolates examined but this may be explained by the relatively restricted degree of spread produced, which was roughly equal to that of the cytophagas NCMB 11 and 292 on $4 \%(w / v)$ peptone agar.

\section{Examination of cell roalls}

Staining of cell walls. Though Bacillus cereus when used as a readily stainable control gave excellent results, all the test isolates were less satisfactory. This was not unexpected since Hale \& Bisset (1956) found that Gram-positive bacteria were far more readily stainable than Gram-negative ones. An additional disadvantage was that, in the majority of cases, the cells were so small or slender that even with a good staining technique the walls would be difficult to discern. However a few definite results were obtained which could be summarized as follows: (1) cell walls were not seen in the case of the cytophagas (NCMB 292, 11); (2) distinct cell walls were observed in groups 2 and 3 isolates and also in some of the 14 Gram-negative non-motile isolates which were not grouped; $(3)$ the remaining isolates included those in which cell walls could probably be discerned (e.g. other isolates in groups 2 and 3) and those where the demonstration of walls was virtually impossible because of the small size of the cells (e.g. group 1 isolates).

Cell-wall analysis. The results (see Table 5) show that the 6 isolates examined formed a homogeneous group with regard to the amino acids identified. Those amino acids which gave the stronger spots with strains мСмв 251 and 253, the cytophaga NCMB 11 and Flavobacterium aquatile were the only ones detected in strains NCMB 244 and 249, where smaller amounts of material were available (see Methods). The isolates studied had a fairly wide range of amino acids in their cell walls; this is true of most Gram-negative bacteria (Salton, 1956). The results for the cytophaga confirm those of Mason \& Powelson (1958) who, by hydrolysis of the cell wall of Myxococcus xanthus, identified 17 amino acids including the 12 detected in the present work; these authors concluded that the cell walls were similar to those of other Gram-negative bacteria. A quantitative difference was observed with the sugars, the spots being substantially stronger with strain NCMB 251 and $F$. aquatile than with strain NCMB 253 and the cytophaga NCMB 11. The absence of sugar spots with strains NCMB 244 and 249 may probably be explained by the smaller amounts of material chromatographed. The detection of sugars in the cell wall of the cytophaga confirms the findings of Mason \& Powelson (1958) who identified galactose, glucose and rhamnose from $M$. xanthus. The failure to detect glucosamine and muramic acid was probably due to the low concentrations of hexosamines normally found in Gram-negative bacteria (Salton, 1956), though the isolation of an unidentified hexosamine from $M$. xanthus (Mason \& Powelson, 1958) suggests the concentrations may differ.

\section{DISCUSSION}

It is probable that each of the groups 1-4 merits species rank and the members of the groups are strains. Groups 2 and 3 are sufficiently close to the description of the genus Flavobacterium in Bergey's Manual (1957) to justify their inclusion 
in the genus, although a comparison between these groups and the species listed in Bergey's Manual shows that neither of the groups is sufficiently like any named species as to be identical to it; in addition to groups 2 and 3, the 14 Gram-negative non-motile isolates are also regarded as Flavobacterium species. Groups 1 and 4 would also be included as Flavobacterium species except that spreading colonies were formed. The inclusion of the motile bacteria ( questionable since their properties are so very different from the non-motile flavobacteria examined. Since polarly flagellate yellow-pigmented organisms have been excluded from the genus the retention of peritrichous forms could be further criticized; a new genus could therefore be suggested for the peritrichous forms.

The absence of a demonstrable cell wall is given as a characteristic of myxobacteria in Bergey's Manual (1957) but the chemical composition of the cell walls of the cytophaga examined clearly has certain affinities with the cell walls of the flavobacteria. An additional property of myxobacteria is reputed to be that of flexion or vigorous bending of individual organisms; this has been observed by many workers (e.g. Bachmann, 1955). However no flexion was noticed in the present work and it may be a feature of doubtful significance as suggested by Anderson \& Ordal (1961).

The only property which distinguishes flavobacteria from cytophaga experimentally appears to be that of spreading growth. Any non-flagellate bacterium which shows spreading growth should exhibit some form of gliding motility. Gliding motility is accepted as one of the principal distinguishing properties of the genus Cytophaga (Bergey's Manual, 1957); thus all non-flagellate bacteria which have this property may be considered as myxobacteria. The majority of group 1 and all group 4 isolates swarmed readily under certain conditions; they are therefore identified as presumptive Cytophaga species. Those isolates from group 1 which did not swarm are retained in the group because of their otherwise similar properties. Therefore, besides the cytophagas NCMB 11 and 292, a further 20 isolates are likely to be cytophagas.

There is a great similarity between the properties of the swarming and nonswarming isolates in this work; the swarming isolates have a greater heat resistance than the typical flavobacteria and this is the only other characteristic which differentiates these two groups. The similarity between the swarming and nonswarming isolates examined suggests that the affinities between flavobacteria and cytophagas may be stronger than appears. Further work is necessary to establish whether or not the properties of swarming, flexion and non-stainable cell walls are specific to myxobacteria; the study of this problem must be extended to include both non-marine and marine named species of the two genera.

I should like to thank Drs J. M. Shewan and G. D. Floodgate for advice in the preparation of this paper. This work was financed by the Development Commission and carried out by a Research Fellow of the Department of Bacteriology, University of Aberdeen, as part of the research programme of the Department of Scientific and Industrial Research. It formed part of an M.Sc. thesis for Birmingham University. 


\section{REFERENCES}

Anderson, R. L. \& Ordal, E. J. (1961). Cytophaga succinicans sp.n., a facultatively anaerobic, aquatic myxobacterium. J. Bact. 81, 130.

BachmanN, B. J. (1955). Studies on Cytophaga fermentans, n.sp., a facultatively anaerobic lower myxobacterium. J. gen. Microbiol. 13, 541.

Benton, A. G. (1935). Chitinivorous bacteria-a preliminary survey. J. Bact. 29, 449.

Bergey's Manual of Determinative Bacteriology (1923). 1st ed. Ed. by D. H. Bergey, F. C. Harrison, R. S. Breed, B. W. Hammer \& F. M. Huntoon. Baltimore: Williams and Wilkins.

Bergey's Manual of Determinative Bacteriology (1939). 5th ed. Ed. by D. H. Bergey, R. S. Breed, E. G. D. Murray \& A. P. Hitchens. London: Baillière, Tindall and Cox.

Bergey's Manual of Determinative Bacteriology (1957). 7th ed. Ed. by R. S. Breed, E. G. D. Murray \& N. R. Smith. London: Baillière, Tindall and Cox.

Brisou, J., Tysser, C. \& VACher, B. (1959). Recherches sur les Pseudomonadaceae. Étude de deux souches de Flavobacterium isolées des poissons d'eau douce. Ann. Inst. Pasteur, 96, 633.

Christensen, W. B. (1946). Urea decomposition as a means of differentiating Proteus and Paracolon cultures from each other and from Salmonella and Shigella types. J. Bact. $52,461$.

CoNNELL, J. J. (1958). Studies in the proteins of fish skeletal muscle. 5. Molecular weight and shape of cod fibrillar proteins. Biochem. J. 70, 81 .

Cummins, C. S. \& Harris, H. (1956). The chemical composition of the cell wall in some Gram-positive bacteria and its possible value as a taxonomic character. J. gen. Microbiol. 14, 583.

Ferrari, A. \& ZanNini, E. (1958). Ricerche sulle specie der genere Flavobacterium. Ann. Microbiol. Enzim. 8, 138.

GaRY, N. D. (1950). A taxonomic study of the genus Flavobacterium Bergey et al. M.A. thesis, Indiana.

Georgala, D. L. (1957). Quantitative and qualitative aspects of the skin flora of North Sea cod and the effect thereon of handling on ship and on shore. Ph.D. thesis, Aberdeen.

Gibson, T. (1955). General morphology. J. gen. Microbiol. 12, 324.

HALE, C. M. F. (1953). The use of phosphomolybdic acid in the mordanting of bacterial cell walls. Lab. Pract. 2, 115.

HaLe, C. M. F. \& Bisset, K. A. (1956). A comparison of the staining reactions of the cell walls of Azotobacter chroococcum and those of Gram-positive and Gram-negative bacteria. J. gen. Microbiol. 15, 423.

Hough, L., Jones, J. K. N. \& Wadman, W. H. (1950). Quantitative analysis of mixtures of sugars by the method of partition chromatography. 5. Improved methods for the separation and detection of the sugars and their methylated derivatives on the paper chromatogram. J. chem. Soc. p. 1702.

HUGH, R. \& LeIFson, E. (1953). The taxonomic significance of fermentative versus oxidative metabolism of carbohydrates by various Gram negative bacteria. J. Bact. 66, 24.

Humm, H. J. (1946). Marine agar-digesting bacteria of the South Atlantic coast. Bull. Duke Univ. Mar. Sta. 3, 43.

KADOTA, H. (1956). A study on the marine aerobic cellulose-decomposing bacteria. Mem. Coll. Agric. Kyoto, No. 74 (Fisheries Series No. 6), 1.

Kovacs, N. (1956). Identification of Pseudomonas pyocyanea by the oxidase reaction. Nature, Lond. 178, 703.

Macleod, R. A., ONofrey, E. \& Norris, M. E. (1954). Nutrition and metabolism of marine bacteria. 1. Survey of nutritional requirements. J. Bact. 68, 680.

Mason, D. J. \& Powerson, D. (1958). The cell wall of Myxococcus xanthus. Biochim. biophys. Acta, 29, 1.

Partridge, S. M. (1949). Aniline hydrogen phthalate as a spraying reagent for chromatography of sugars. Nature, Lond. 164, 443. 
Paton, A. M. (1959). Enhancement of pigment production by Pseudomonas. Nature, Lond. 184, 1254.

Prince, H. N., Beck, E. S., Cleverdon, R. C. \& Kulp, W. L. (1954). The flavobacteria. 1. Nutritional requirements. J. Bact. 68, 326.

Prince, H. N. \& Cueverdon, R. C. (1955). The flavobacteria. 2. Utilization of nitrogen compounds. J. Bact. 69, 307.

Salton, M. R. J. (1956). Bacterial cell walls. In Bacterial Anatomy. Symp. Soc. gen. Microbiol. 6, 81.

SHewAN, J. M. (1949). Some bacteriological aspects of handling, processing and distribution of fish. J. R. sanit. Inst. 69, 394.

Shewan, J. M., Hodgkiss, W. \& Liston, J. (1954). A method for the rapid differentiation of certain non-pathogenic, asporogenous bacilli. Nature, Lond. 173, 208.

Staining Procedures, Biological Stain Commission (1947). 2nd edn. Ed. by H. J. Conn \& M. A. Darrow. Geneva, New York: Biotech. Publications.

Stanier, R. Y. (1947). Studies on non-fruiting myxobacteria. 1. Cytophaga johnsonae, n.sp., a chitin-decomposing myxobacterium. J. Bact. 53, 297.

Starr, T. J. \& Ordal, E. J. (1953). A study of marine myxobacteria. Tech. Rep. No. 14, Office of Naval Research, U.S.A.

TARR, H. L. A. (1954). Microbiological deterioration of fish post mortem, its detection and control. Bact. Rev. 18, 1.

Topley and Wilson's Principles of Bacteriology and Immunity (1955), 4th edn. Ed. by G. S. Wilson \& A. A. Miles. London: Edward Arnold.

VELANKAR, N. K. (1957). Bacteria isolated from sea-water and marine mud off Mandapam (Gulf of Mannar and Palk Bay). Indian J. Fish. 4, 208.

WeEKs, O. B. (1955). Flavobacterium aquatile (Frankland and Frankland) Bergey et al., type species of the genus Flavobacterium. J. Bact. 69, 649.

WEEKs, O. B. \& BECK, S. M. (1960). Nutrition of Flavobacterium aquatile strain Taylor and a microbiological assay for thiamine. J. gen. Microbiol. 23, 217.

Wood, A. J. \& BAIRD, E. A. (1943). Reduction of trimethylamine oxide by bacteria. 1. The Enterobacteriaceae. J. Fish. Res. Bd Can. 6, 194.

ZoBeu,, C. E. (1946). Marine Microbiology. Waltham, Mass.: Chronica Botanica. 